\title{
ODONTOMETRIC ANALYSIS OF PERMANENT CANINES IN A BRAZILIAN POPULATION FOR THE INVESTIGATION OF SEXUAL DIMORPHISM
}

\author{
ANÁLISE ODONTOMÉTRICA DE CANINOS PERMANENTES DE UMA \\ POPULAÇÃO BRASILEIRA APLICADA AO DIMORFISMO SEXUAL
}

\author{
Silvia Sayuri SHIMADA ${ }^{1}$; Érica Camargo da SILVA ${ }^{\mathbf{1}}$; Livia Graziele RODRIGUES ${ }^{2}$; \\ Rhonan Ferreira SILVA ${ }^{3}$; Érica Miranda de TORRES ${ }^{4}$; Ricardo Tadashi SHIMADA ${ }^{5}$ \\ 1. Discente de Odontologia, Faculdade de Odontologia, Universidade Federal de Goiás, Goiás, Brasil; 2. Mestre em Odontologia, \\ Faculdade de Odontologia, Universidade Federal de Goiás, Goiás, Brasil; 3. Docente do Programa de Pós-graduação em Odontologia, \\ área de Odontologia Legal, Universidade Federal de Goiás, Goiás, Brasil; 4. Docente da Faculdade de Odontologia, área de Metodologia \\ Científica, Universidade Federal de Goiás, Goiás, Brasil; 5. Ortodontista, Instituto Ricardo Shimada, Goiás, Brasil. \\ silvia.shimada@hotmail.com.
}

\begin{abstract}
Objective: The present study aimed to investigate the potential of permanent canines for sexual dimorphism in a Brazilian population. Methods: The sample consisted of 172 dental casts from females $(n=102)$ and males $(n=70)$ aged between 13 and 49 years old. Each dental cast underwent mesiodistal (MD) and buccolingual (BL) measurement of the permanent canines using a digital caliper and a bow compass. MD and BL dimensions were compared between sex groups using Student's t-test for independent samples. Results: Statistically significant differences were observed comparing the odontometric information between females and males $(\mathrm{p}<0.05)$. Conclusion: These findings indicate that permanent canines have metric characteristics to enable sexual dimorphism, becoming useful for Brazilian forensic services.
\end{abstract}

KEYWORDS: Canine tooth. Sex characteristics. Sex dimorphism. Forensic dentistry. Forensic anthropology.

\section{INTRODUCTION}

The identification of mutilated, charred and skeletonized bodies is one of the main tasks in forensic anthropology, in which the reconstruction of a biological profile of the victim is performed retrieving information related to age, sex, stature and ancestry from physical traits (VANRELL, 2009). Specifically, sex determination is usually obtained qualitatively and quantitatively by analyzing the pelvis and skull bones (VANRELL, 2009). However, in certain situations these bones are fragmented or not available, making necessary the analysis of alternative material, such as the human teeth. Teeth are the most resistant structures of the human body, maintaining integrity even under the influence of chemical, biological and physical agents, as well as post-mortem alterations, such as putrefaction. In forensics, they are considered appropriate material for anthropological assessment (KAUSHAL et al., 2003; JOFRÉ et al., 2009).

Sex determination through dental traits may be reliably performed measuring mesiodistal (MD) and buccolingual (BL) dimensions of permanent teeth (KAUSHAL et al., 2003). Mostly, these dimensions trend to be larger in males compared to females of the same population. Garn et al. (1967) compared the dental MD dimensions of 111 dental casts of female siblings from 73 different North
American families, noticing larger teeth in males, especially canines and first molars. Accordingly, Bishara et al. (1989) compared the MD and BL dimensions of teeth from female and male Egyptians, North Americans and Mexicans. The teeth from Egyptian males were larger compared to females, except for the incisors. Similarly, the teeth from North American males were larger than females, except by the MD dimension in upper left lateral incisors. In the Mexican population, all dimensions in males were larger for all tooth groups. Dental dimorphism expressed within larger teeth in males was also confirmed by Yuen et al. (1995) within a Chinese population; Hattab et al. (1996) within a Jordanian population; Yamaguto et al. (2005) and Costa et al. (2010) within Brazilian populations; Jofré et al. (2009) within Spanish and Chilean populations; and by Jain et al. (2011) and Singh et al. (2015) within an Indian population.

Despite converging towards the confirmation of sexual dimorphism, the current scientific literature suggests that different levels of dimorphism are expressed within specific populations and tooth groups. This phenomenon may be potentially increased considering large countries with heterogeneous miscegenation. Based on that, the present study aimed to analyze quantitatively permanent canines of a Brazilian 
population in order to verify forensic application for sexual dimorphism.

\section{MATERIAL AND METHODS}

This study was conducted after approval of the Committee for Ethics in Research of the Federal University of Goias (protocol 1.148.414/2015).

The sample size was calculated using the mean measurement values and standard deviations of canine dimensions from a previous study with a Brazilian population (YAMAGUTO et al., 2005). Considering an expected measurement difference between females and males of approximately $0.5 \mathrm{~mm}$, type I error of $5 \%($ alpha $=0.05)$ and type II error of $20 \%$ (power $=80 \%$ ), the ideal sample was calculated for containing at least 18 dental casts for each sex group (female and male). Based on that, the collected sample consisted of 172 dental casts from 102 females and 70 from males aged between 13 and 49 years old. All the dental casts were confectioned for orthodontic purposes. The inclusion criteria consisted on the complete clinical eruption of permanent canines, while the exclusion criteria comprehended dental casts with crowded, impacted, fractured, rotated, and decayed teeth, as well as teeth that underwent orthodontic interproximal stripping.

The eligible dental casts underwent measurement of MD and BL dimensions of the canines. All the measurements were performed with dental casts placed on a flat surface. Photographs of each dental cast were performed in occlusal view implementing an ABFO \#2 scale (American Board of Forensic Odontology Inc., USA). The MD measurements were taken positioning a digital bow compass in the most mesial and distal points of the canines, while the BL measurements were taken with a digital caliper positioned in the most buccal and lingual points of the canines (Figure 1). More specific the device was aligned with the vertical axis of each canine.
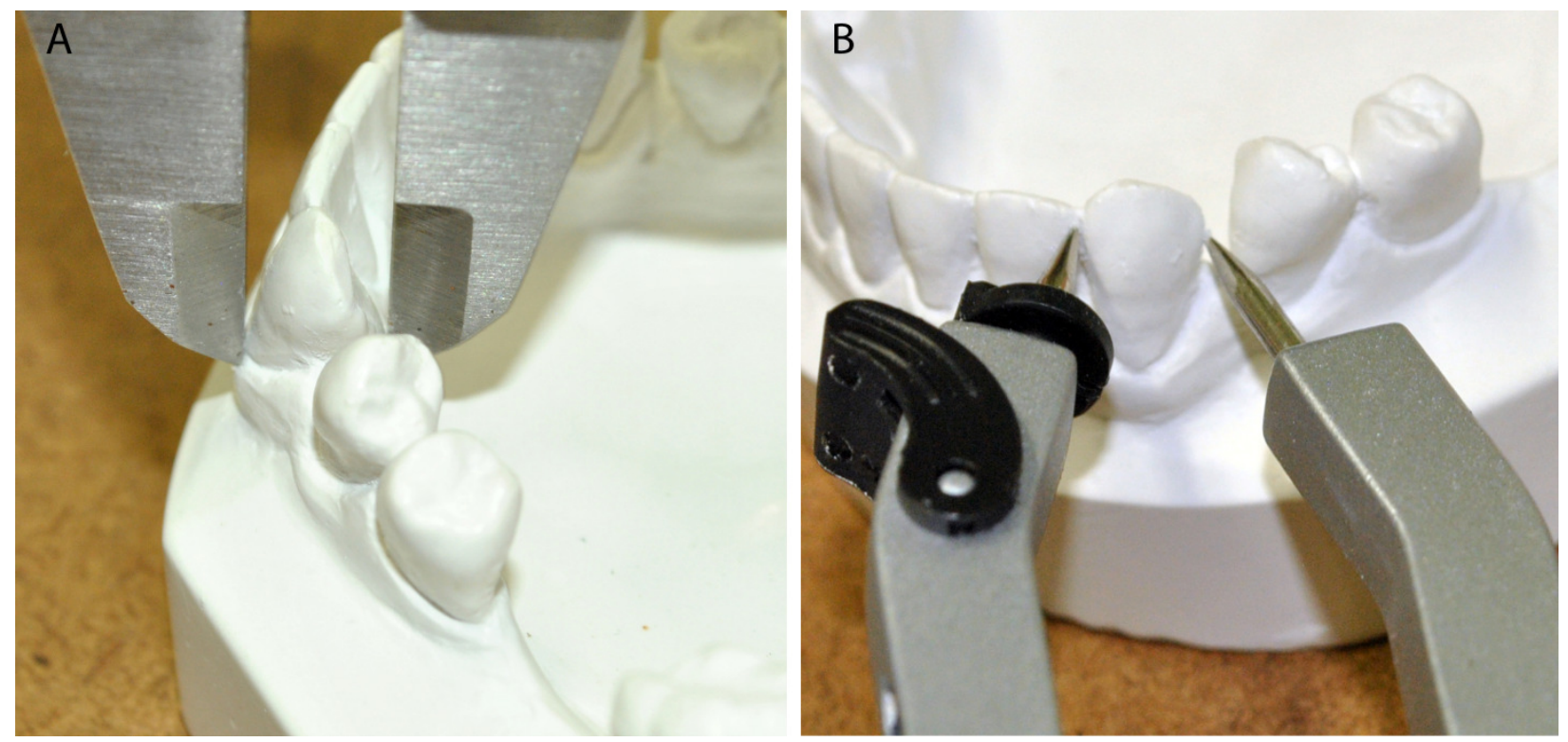

Figure 1. Illustration of the position of the instruments used to measure the bucolingual (A) and mesio-distal (B) dimensions of the permanent canines

The measurements were performed in two different moments within 30 days interval by two trained and previously calibrated examiners. The obtained measurement dimensions were tabulated and correlated with sex information, preserving any identification data. Statistical tests consisted of Intraclass Correlation Coefficient (ICC) for testing the inter-examiner reproducibility; KolmogrovSmirnov for testing the variables for normality; Levene test for verifying the homogeneity of the variances; and Student's t-test for independent samples for comparing mean values between sex groups. All the statistical analyses were performed using SPSS 21.0 (SPSS Inc., Illinois, USA) software with significance level of $5 \%$.

\section{RESULTS AND DISCUSSION}

Examiner reproducibility reached optimal outcomes $(>0.9)$.

In females the mean values of measured MD dimensions ranged from $6.53 \mathrm{~mm}( \pm 0.41 \mathrm{~mm})$ to $7.49 \mathrm{~mm}( \pm 0.46 \mathrm{~mm})$, while the mean BL dimensions ranged between $7.19 \mathrm{~mm}( \pm 0.51 \mathrm{~mm})$ and $7.87 \mathrm{~mm}$ 
$( \pm 0.49 \mathrm{~mm})$. In males the mean values of measured MD dimensions ranged from $6.94 \mathrm{~mm}( \pm 0.51 \mathrm{~mm})$ to $7.93 \mathrm{~mm}( \pm 0.55 \mathrm{~mm})$, while mean BL dimensions ranged between $7.87 \mathrm{~mm}( \pm 0.45 \mathrm{~mm})$ and $8.42 \mathrm{~mm}$
$( \pm 0.62 \mathrm{~mm})$. A statistically significant difference $(\mathrm{p}<0.05)$ was observed between sex groups for both MD and BL dimensions (Table 1).

Table 1. Mean ( \pm standard deviation) of the measurements obtained for females and males expressed in millimeters

\begin{tabular}{cccc} 
Measurement & \multicolumn{2}{c}{ Sex groups } & $p$ value \\
\cline { 2 - 3 } & Female & Male & \\
BL 13 & $7.85( \pm 0.46)$ & $8.39( \pm 0.59)$ & $>0.001^{*}$ \\
BL 23 & $7.87( \pm 0.49)$ & $8.42( \pm 0.62)$ & $>0.001^{*}$ \\
BL 33 & $7.19( \pm 0.51)$ & $7.87( \pm 0.45)$ & $>0.001^{*}$ \\
BL 43 & $7.24( \pm 0.53)$ & $7.88( \pm 0.43)$ & $>0.001^{*}$ \\
MD 13 & $7.49( \pm 0.46)$ & $7.93( \pm 0.55)$ & $>0.001^{*}$ \\
MD 23 & $7.49( \pm 0.45)$ & $7.89( \pm 0.56)$ & $>0.001^{*}$ \\
MD 33 & $6.54( \pm 0.42)$ & $6.96( \pm 0.50)$ & $>0.001^{*}$ \\
MD 43 & $6.53( \pm 0.41)$ & $6.94( \pm 0.51)$ & $>0.001^{*}$
\end{tabular}

*Statistically significant difference (t-test); BL: buccolingual; MD: mesiodistal; \#13: maxillary right canine; \#23: maxillary left canine; \#33: mandibular left canine; \#43: mandibular right canine.

The human teeth may play an essential role providing sex information in forensic scenarios involving skeletal remains, especially considering victims with non developed secondary sexual traits (HEMANTH et al., 2008). Despite that, retrieving sex-related information from measurements of the human teeth must be performed on a populationspecific basis, once the teeth are influenced by genetic and environmental factors (JOFRÉ et al., 2009; GARN et al., 1967; YUEN et al., 1966; HATTAB et al., 1996).

In the present study, canines were chosen as the ideal teeth to verify dimorphism based on the studies of Garn et al. (1967), Bishara et al. (1989), Yuen et al. (1995), Hattab et al. (1996), and Jain et al. (2011) who found in these teeth major dimorphic expression. When compared to the literature (Table 2 ), the present study reveals higher similarity with the North American and the previous Brazilian (COSTA et al., 2012) populations. However, in general the MD and BL dimensions obtained in the present study were smaller compared to others (JOFRÉ et al., 2009; BISHARA et al., 1989; YUEN et al., 1995; HATTAB et al., 1996; JAIN et al., 2011; SINGH et al., 2015).

As expected, different results were obtained comparing outcomes with studies that previously investigated the dental dimorphism in a Brazilian population (YAMAGUTO et al., 2005; COSTA et al., 2012). It is justified by the potential genetic influence over the heterogeneous Brazilian miscegenation and by the environmental factors that induce different dental traits. These findings highlight the need for further studies with regional
Brazilian samples in order to establish better parameters for sexual dimorphism. Additionally, the differences in outcomes also could be related to the differences in sampling. As suggested previously in the literature (TINOCO et al., 2012), may influence the odontometric analysis, affecting the outcomes. This limitation was tackled in the present study including crowded, impacted, fractured, rotated, and decayed teeth in the exclusion criteria.

The differences in the outcomes of performing sex determination though the odontometric analysis of canines are also observed within studies of other populations - such as Uruguayans (SASSI et al., 2012; GARGANO et al., 2014 ), in which the success rate in the process of sex determination varied depending on the anatomic region considered for measuring. Specifically, high success rates $(>70 \%)$ were observed considering the mesiodistal dimension and the gingivoincisal length of the canines (SASSI et al., 2012). On the other hand and similar to what was exposed in table 2, differences also could be observed between the outcomes of studies within the Uruguayan population. More recently, Gargano et al. (2014) suggested that the odontometric analysis of canines reaches a non-satisfactory success rate for sex determination $(<50.52 \%)$. This discrepancy highlights once more the impact of sampling in the final outcomes suggesting pathways for the best practices in forensic anthropology. 
Table 2. Comparison between the mesiodistal (MD) and buccolingual (BL) measurements of canines between populations, expressed in millimeters

\begin{tabular}{|c|c|c|c|c|c|c|c|c|c|c|c|c|c|c|c|c|c|}
\hline \multirow[t]{4}{*}{ Authors } & \multirow[t]{4}{*}{ Population } & \multicolumn{16}{|c|}{ Sex groups } \\
\hline & & \multicolumn{8}{|c|}{ Female } & \multicolumn{8}{|c|}{ Male } \\
\hline & & \multicolumn{2}{|c|}{13} & \multicolumn{2}{|c|}{23} & \multicolumn{2}{|c|}{33} & \multicolumn{2}{|c|}{43} & \multicolumn{2}{|c|}{13} & \multicolumn{2}{|c|}{23} & \multicolumn{2}{|c|}{33} & \multicolumn{2}{|c|}{43} \\
\hline & & $\mathrm{BL}$ & MD & BL & MD & BL & MD & $\mathrm{BL}$ & MD & BL & MD & BL & MD & BL & MD & BL & MD \\
\hline $\begin{array}{c}\text { Bishara et } \\
\text { al., } 1989\end{array}$ & Egypt & 8.0 & 7.5 & 8.0 & 7.5 & 7.3 & 6.6 & 7.2 & 6.6 & 8.2 & 7.9 & 8.2 & 7.9 & 7.4 & 6.9 & 7.4 & 6.9 \\
\hline $\begin{array}{c}\text { Bishara et } \\
\text { al., } 1989\end{array}$ & exico & 8.0 & 7.6 & 8.0 & 7.3 & 7.1 & 6.5 & 7.2 & 6.4 & 8.6 & 7.9 & 8.5 & 8.0 & 7.5 & 7.0 & 7.5 & 6.9 \\
\hline $\begin{array}{c}\text { Bishara et } \\
\text { al., } 1989\end{array}$ & USA & 7.9 & 7.5 & 7.8 & 7.4 & 7.2 & 6.4 & 7.1 & 6.4 & 8.1 & 7.8 & 8.1 & 7.8 & 7.4 & 6.8 & 7.4 & 6.8 \\
\hline $\begin{array}{c}\text { Yuen et } \\
\text { al., } 1995\end{array}$ & China & - & 8.01 & - & 8.01 & - & 6.92 & - & 6.92 & - & 8.29 & - & 8.29 & - & 7.28 & - & 7.28 \\
\hline $\begin{array}{l}\text { Hattab et } \\
\text { al., } 1996\end{array}$ & Jordan & - & 7.68 & - & 7.57 & - & 6.70 & - & 6.61 & - & 8.10 & - & 7.92 & - & 7.10 & - & 6.94 \\
\hline $\begin{array}{c}\text { Jain et al., } \\
2011\end{array}$ & India & - & 7.62 & - & 7.62 & - & 6.68 & - & 6.68 & - & 7.91 & - & 7.91 & - & 6.98 & - & 6.98 \\
\hline $\begin{array}{c}\text { Jofré et } \\
\text { al., } 2009\end{array}$ & pai & 7.84 & 8.17 & 7.84 & 8.13 & - & - & - & - & 8.53 & 8.48 & 8.43 & 8.60 & - & - & - & - \\
\hline $\begin{array}{c}\text { Jofré et } \\
\text { al., } 2009\end{array}$ & hile & 7.96 & 8.00 & 7.94 & 7.91 & - & - & - & - & 8.66 & 8.64 & 8.52 & 8.65 & - & - & - & - \\
\hline $\begin{array}{l}\text { Costa et } \\
\text { al., } 2010\end{array}$ & $\begin{array}{c}\text { Paraíba } \\
\text { (BR) }\end{array}$ & 7.93 & 7.46 & 7.85 & 7.45 & 7.09 & 6.48 & 7.09 & 6.47 & 8.59 & 8.17 & 8.54 & 8.07 & 7.73 & 6.98 & 7.70 & 6.99 \\
\hline $\begin{array}{l}\text { Yamaguto } \\
\text { et al., } \\
2005\end{array}$ & $\begin{array}{c}\text { Paraná } \\
\text { (BR) }\end{array}$ & - & 7.75 & - & 7.75 & - & 6.69 & - & 6.69 & - & 8.34 & - & 8.34 & - & 7.26 & - & 7.26 \\
\hline $\begin{array}{l}\text { Singh et } \\
\text { al., } 2015\end{array}$ & dia & - & - & - & - & - & 6.35 & - & 6.30 & - & - & - & - & - & 7.32 & - & 7.19 \\
\hline $\begin{array}{c}\text { Present } \\
\text { study, } \\
2016 \\
\end{array}$ & $\begin{array}{c}\text { Goiânia } \\
\text { (BR) }\end{array}$ & 7.85 & 7.49 & 7.87 & 7.49 & 7.19 & 6.54 & 7.24 & 6.53 & 8.39 & 7.93 & 8.42 & 7.89 & 7.87 & 6.96 & 7.88 & 6.94 \\
\hline
\end{tabular}

BL: buccolingual; MD: mesiodistal; \#13: maxillary right canine; \#23: maxillary left canine; \#33: mandibular left canine; \#43: mandibular right canine; BR: Brazil. 
Ideally, further researchers in the field should be designed avoiding potential limitations in the methodology, such as the confection of plaster models from dental impressions. In this context, intraoral scanning arises as an option to overcome operator-depending bias minimizing the distortion inherent to the confection of dental casts. The measuring procedures could be performed digitally guided by computer systems in the attempt to reduce the potential error. Further on, algorithms for automated measurements could be developed reducing the operator interaction with the data analysis as well. Finally, a systematic literature review could be useful to screen the current panorama in the application of odontometric information for sex determination in forensic and anthropological sciences.

\section{CONCLUSION}

The present study confirmed the expression of sexual dimorphism in the MD and BL dimensions of the permanent human canines. Additionally, differences were observed confronting the present findings with previous studies with Brazilian populations, revealing the need and encouraging further studies with regional samples.

RESUMO: Objetivo: O presente estudo objetivou avaliar o potencial de caninos permanentes para dimorfismo sexual aplicado à prática forense. Métodos: A amostra consistiu de 172 modelos de gesso odontológicos de pacientes do sexo feminino $(n=102)$ e masculino $(n=70)$ de idades entre 13 e 49 anos. Cada modelo odontológico foi submetido à mensuração dos diâmetros mesiodistal (MD) e bucolingual (BL) utilizando um paquímetro digital e um compasso de ponta seca. Os valores obtidos para cada diâmetro foram comparados entre sexos por meio do teste T de Student para amostras independentes. Resultados: Diferenças com significância estatística foram observadas comparando os achados obtidos para os sexos feminino e masculino $(\mathrm{p}<0.05)$. Conclusão: Estes resultados indicam que os caninos permanentes apresentam características morfométricas capazes de diferenças sexos, sendo uma ferramenta útil para os serviços de Odontologia e Antropologia Forense do Brasil.

PALAVRAS-CHAVE: Caninos; Sexo; Dimorfismo; Odontologia Forense; Antropologia Forense.

\section{REFERENCES}

BISHARA, S. E.; ABDALLAH, E. M.; GARCIA, A. F. Comparisons of mesiodistal and buccolingual crown dimensions of the permanent teeth in three population from Egypt, Mexico, and the United States. Am. J.

Orthod. Dentofac. Orthop. Saint Louis. v. 96, n. 5, p. 416-422, nov. 1989.

COSTA, Y. T. F.; LIMA, L. N. C.; RABELLO, P. M. Analysis of canine dimorphism in the estimation of sex. Braz. J. Oral Sci. Piracicaba. v. 11, n. 3, p. 406-410, jul/sep. 2012.

GARGANO, V.; PICAPEDRA, A.; ETCHEGOYEN, C. A. S.; LIMA, L. N. C.; ALVAREZ, R.; FRANCESQUINI JÚNIOR, L.; DARUGE JUNIOR, E. Son los índices caninos mandibular y maxilar herramientas fidedignas para ladeterminación del sexo? Actas Odontológicas. Montevidéu. v. 11, n. 2, p. 22 34, dec. 2014.

GARN, S. M.; LEWIS, A. B.; KEREWSKY, R. S. Communalities in the size differences of teeth of brothers and sisters. Arch. Oral Biol. New York. v. 12, n. 5, p. 575-581, may. 1967.

HATTAB, F. N.; AL-KHATEEB, S.; SULTAN, I. Mesiodistal crown diameters of permanent teeth in Jordanians. Arch. Oral Biol. New York. v. 41, n. 7, p. 641-645, jul. 1996.

HEMANTH, M.; VIDYA, M.; NANDAPRASAD, BHAVANA, V. K. Sex determination using dental tissue. Med. Legal Update. New Delhi.v. 8, n. 2, p. 7-12, jul/dec. 2008. 2008.

JAIN, A. K.; GARG, N.; SINGH, J.; ANSARI, A.; SANGAMESH, B. Mesiodistal crown dimensions of the permanent dentition of a North Indian population. Ind. J. Dent. Punjab. v. 2, n. 2, p. 16-20, jun. 2011. 
JOFRÉ, C. A.; VALENZUELA, J. S. P.; GALDAMES, I. S. Sexual dimorphism in the tooth dimensions of Spanish and Chilean peoples. Int. J. Odontostomat. Temuco. v. 3, n. 1, p. 47-50, jul. 2009.

KAUSHAL, S.; PATNAIK, V. V. G.; AGNIHOTRI, G. Mandibular canines in sex determination. J. Anat. Soc. India. New Delhi. v. 52, n. 2, p.119-124, dec. 2003.

SASSI, C.; PICAPEDRA, A.; LIMA, L. N. C.; FRANCESQUINI JÚNIOR, L.; DARUGE, E.; DARUGE JUNIOR, E. Sex determination in Uruguayans by odontometric analysis. Braz. J. Oral Sci. Piracicaba. v. 11, n. 3, p. 381-386, sep. 2012.

SINGH, S. K.; GUPTA, A.; PADMAVATHI, B.; KUMAR, S.; ROY, S.; KUMAR, A. Mandibular canine index: a reliable predictor for gender identification using study cast in Indian population. Ind. J. Dent. Res. New Delhi.v. 26, n. 4, p. 396-399, jul/aug. 2015.

VANRELL, J. P. Odontologia legal e antropologia forense. Rio de Janeiro: Guanabara Koogan, 2009. TINOCO, R. L. R.; CORREIA LIMA, L. N.; OLIVEIRA, O. F.; SILVA, R. F.; DARUGE JUNIOR, E. Sex determination by mandibular canine index? Accuracy on a mixed population from Brazil. Int. J. Dent. Anthropol. Bogotá.v. 21, n. 1, p. 13-21, jul. 2012.

YAMAGUTO, O. T.; VASCONCELOS, M. H. F. Determination of mesiodistal dental measures in white Brazilian individuals with normal occlusion. R. Dental Press Ortodon. Ortop. Facial. Maringá. v. 10, n. 5, p. 99-107, sep/oct. 2005.

YUEN, K. K.; TANG, E. L.; SO, L. L. Relations between the mesiodistal crown diameters of the primary and permanent teeth of Hong Kong Chinese. Arch. Oral Biol. New York .v. 41, n. 1, p. 1-7, jan. 1996. 